\title{
Testicular Typical Seminoma
}

National Cancer Institute

\section{Source}

National Cancer Institute. Testicular Typical Seminoma. NCI Thesaurus. Code C61383.

A testicular seminoma characterized by the presence of uniform round germ cells with glycogen-rich cytoplasm and large nuclei, and a lymphocytic infiltrate. 